\title{
Agnieszka Brzosko-Sermak
}

Uniwersytet Pedagogiczny im. Komisji Edukaji Narodowej w Krakowie

e-mail: abrzosko@up.krakow.pl

\section{SOCJOTECHNIKA \\ W GOSPODARCE PRZESTRZENNEJ}

\section{SOCIAL ENGENEERING IN SPATIAL ECONOMY}

DOI: $10.15611 /$ pn.2018.504.02

JEL Classification: R (Urban, Rural, Regional, Real Estate, and Transportation Economics)

\begin{abstract}
Streszczenie: Celem artykułu było przedstawienie możliwości wykorzystania wiedzy socjotechnicznej w kształtowaniu i wzmacnianiu ładu przestrzennego w miastach. Szczegółowo zaprezentowana została procedura użycia zespołu dyrektyw socjotechnicznych opisujących, jak wprowadzać celowe zmiany przy użyciu określonych środków, na bazie oceny i ustalonych wartości. Autorka zaprezentowała możliwości wykorzystania socjotechniki urbanistycznej, posługując się przykładami z zakresu planowania przestrzennego, funkcjonowania miast oraz monitorowania tego funkcjonowania. Wskazane zostały najbardziej pożądane przyszłe kierunki przemian miejskich jednostek osadniczych w Polsce. Wyniki rozważań wskazują, w jaki sposób należy łączyć wiedzę teoretyczną z zakresu socjologii i gospodarki przestrzennej w miastach z możliwymi, a nawet pożądanymi działaniami zmierzającymi do osiągania zamierzonych celów w funkcjonowaniu miasta i jego rozwoju.
\end{abstract}

Słowa kluczowe: socjotechnika, socjotechnika urbanistyczna, planowanie przestrzenne, gospodarka przestrzenna, ład przestrzenny.

Summary: The aim of the article was to present the possibility of using sociotechnical knowledge in shaping and strengthening spatial order in cities. The procedure for using a set of social engineering directives describing how to make targeted changes using specific measures is based on the evaluation and established values. The author presents the possibilities of using urban social engineering using examples of spatial planning, city functioning and monitoring of this functioning. The results of the reflections show how to combine the theoretical knowledge in the field of sociology and urban space management.

Keywords: social engeneering, urban social engeneering, spatial planning, spatial economy, spatial order.

\section{Wstęp}

Działania ludzkie w dążeniu do uzyskania ładu przestrzennego, czyli nadrzędnego celu gospodarki przestrzennej, w istocie koncentrują się na osiągnięciu optymalnej struktury przestrzennej, społecznej i funkcjonalnej w miastach. Wspomniany proces 
powinien przebiegać w sposób planowy i być świadomie zarządzany, nie tylko przy zaangażowaniu władz, samorządów czy grup społecznych, lecz także jako wspólne dzieło całych społeczności lokalnych.

Interdyscyplinarne poszukiwanie narzędzi uwzględniających ład przestrzenny w miastach staje się niezbędne, jeśli brać pod uwagę wielowymiarowość i złożoność problemów, z jakimi obecnie takie jednostki muszą się mierzyć. Sama istota powstawania, rozwoju, przemian i funkcjonowania miast skłania do włączenia wiedzy z zakresu socjologii do dobrze znanych działań w zakresie gospodarki przestrzennej. Społeczne aspekty rozwoju miast, procesy urbanizacji, a także zagadnienia związane z przestrzeniami społecznymi czy społecznościami lokalnymi nie mogą być pomijane w dążeniu do uzyskania trwałego ładu przestrzennego.

Aby to jednak osiągnąć, nie wystarczy tylko połączyć wiedzę z obu dziedzin, trzeba posiąść umiejętność trafnego, skutecznego i długotrwałego wprowadzania zamierzonych celów w życie. Pomocą w tym zakresie może służyć socjotechnika urbanistyczna [Karwińska (red.) 2015], a jej efekty można zastosować w planowaniu przestrzennym, podtrzymywaniu bądź osiąganiu właściwego/pożądanego funkcjonowania miast oraz w monitorowaniu tego funkcjonowania. Warto dodać, że opisane w artykule czynności mogą być podejmowane na różnych poziomach - od skali całego miasta, poprzez dzielnice, do mikrośrodowisk społecznych - dzięki czemu są one dość uniwersalne.

Celem artykułu było pokazanie możliwości wykorzystania wiedzy socjotechnicznej we wzmacnianiu i kształtowaniu ładu przestrzennego w miastach. W tym celu została użyta procedura zgodna $\mathrm{z}$ tokiem postępowania celowościowego w socjotechnice, na podstawie której sporządzono plan działania zawierający dyrektywy socjotechniki urbanistycznej [Karwińska (red.) 2015].

Literatura odnosząca się do tej części socjologii, jaką jest socjotechnika, dzieli się w zależności od warstw znaczeniowych przypisywanych temu terminowi. Jest to też źródło nieporozumień i trudności interpretacyjnych [Kubin 2000], gdyż dominujące jest w myśleniu potocznym rozumienie socjotechniki jako synonimu manipulacji. Niefortunnie taki sposób pojmowania tego terminu redukuje go do bardzo wąskiego rozumienia, gdzie ,życie zbiorowe traktuje się jako kombinację działań zmierzających wyłącznie do osiągnięcia korzyści indywidualnych" [Frieskie 2000, s. 41]. W niniejszej pracy socjotechnika rozumiana jest ,jako zespół dyrektyw socjologicznych opisujących, jak wprowadzać celowe zmiany społeczne przy użyciu określonych środków, w oparciu o oceny i wartości społeczne" [Karwińska (red.) 2015, s. 19].

\section{Lad przestrzenny a wiedza socjologiczna}

Gospodarka przestrzenna jest złożoną dziedziną naukową, która ma przynajmniej dwa, bardzo ważne przełożenia na otaczającą nas rzeczywistość. Po pierwsze wyjaśnia procesy zachodzące w przestrzeni, dzięki czemu przybliżone zostają przyczyny 
zróżnicowań przestrzennych procesów gospodarczych; dodatkowo wyjaśniane zostaje kształtowanie się systemów osadniczych. Drugą wspomnianą ważną funkcją gospodarki przestrzennej jest jej możliwość oddziaływania na przestrzeń. Zarówno w kontekście, jak powinna być ona zagospodarowana jako „dobro rzadkie”, jak i poprzez zarządzanie relacjami człowiek-gospodarka-przestrzeń [Domański 2016].

Nie należy również zapomnieć o nadrzędnym celu gospodarki przestrzennej, jakim jest ład przestrzenny, dążący do uzyskania określonej struktury przestrzennej i funkcjonalnej, będący pewną organizacją przestrzenną terytorialnego systemu społecznego spełniającą kryteria racjonalności ogólnospołecznej [Parysek 2006]. W rozumieniu słownikowym oraz potocznym najczęstszą definicją ładu przestrzennego jest porządek, równowaga i harmonia [Karwińska 2008]. Ustawa o planowaniu i zagospodarowaniu przestrzennym [Ustawa z 27 marca 2003] natomiast definiuje ten termin jako: „takie ukształtowanie przestrzeni, które tworzy harmonijną całość oraz uwzględnia w uporządkowanych relacjach wszelkie uwarunkowania i wymagania funkcjonalne, społeczno-gospodarcze, środowiskowe, kulturowe oraz kompozycyjno-estetyczne".

Złożoność relacji, jakie muszą być wzięte pod uwagę, aby w odpowiedni sposób kształtować ład przestrzenny, a także występowanie wśród nich aspektów społecznych czy kulturowych, skłaniają badaczy do czerpania z innych dziedzin, bardziej związanych ze sferą społeczną. Socjologia badająca reguły, procesy i struktury łączące i dzielące ludzi, a także więzi międzyludzkie i procesy ich zmian jest dobrym uzupełnieniem wiedzy z zakresu gospodarki przestrzennej. Gdy sięgnie się głębiej do poszczególnych działów socjologii, można zauważyć jeszcze większe korzyści interdyscyplinarnego podejścia do rozwiązywania problemów przestrzennych. Przykładem może być socjologia miast zajmująca się społecznymi aspektami rozwoju miast, zagadnieniami związanymi z przestrzeniami społecznymi, urbanizacją czy społecznościami lokalnymi [Majer 2010].

Chcąc mieć realny wpływ na ład przestrzenny i funkcjonowanie ośrodków miejskich, z bogatej wiedzy teoretycznej czerpanej z różnych dziedzin należy przejść na poziom działania. W zakresie socjologii jest to skierowanie się w stronę socjotechniki, z jednoczesnym odrzuceniem wąskiego i w naukowym rozumieniu - wypaczonego pojmowania tego terminu jako wiedzy służącej przede wszystkim realizacji interesów własnych jednostki, a więc wiedzy manipulatywnej [Karwińska (red.) 2015], o czym wspominano już wcześniej. Gospodarka przestrzenna ma szansę skorzystać z ciekawego instrumentu socjotechniki, jeżeli otworzy się na jej rozumienie przedstawione przez A. Podgóreckiego jako ,zespołu zaleceń dotyczących tego, jak dokonywać świadomych przekształceń społecznych po to, aby osiągnąć zamierzone cele" [Podgórecki 1966, s. 33]. Autor zaprezentował tezy, które wyznaczyły główny kierunek rozważań nad socjotechniką, były to:

1. Socjotechnika jest nauką praktyczną.

2. Przedmiotem teoretycznej refleksji i praktyki socjotechnicznej jest racjonalna zmiana rzeczywistości społecznej. 
Agnieszka Brzosko-Sermak

3. Główne obszary zastosowań oddziaływań socjotechnicznych to: system prawny, system wychowania, techniki masowego oddziaływania, sposoby kierowania ludźmi.

4. Źródłem wiedzy socjotechnicznej są twierdzenia socjologii, zasady działania wykształcone w toku praktyki społecznej i refleksje myślicieli.

5. Podstawowymi wypowiedziami socjotechniki są oceny utylitarne.

6. Socjotechnika jest neutralna etycznie, nie zajmuje się oceną ani celów, ani narzędzi działania.

Tak rozumiana socjotechnika została szeroko zaakceptowana jako odrębna nauka społeczna [Kwaśniewski 2000]. Chcąc jednak zaadaptować ją na cele gospodarki przestrzennej, konieczne było zmodyfikowanie jej podstaw teoretycznych. Pierwszą taką próbę podjął K. Przecławski [1964], wskazując formy współdziałania socjologów i urbanistów. Następnie B. Jałowiecki [1968] chciał połączyć wiedzę socjologiczną z planowaniem przestrzennym. Kontynuatorem tego podejścia był Z. Pióro, który chciał rozszerzyć udział socjologii w planowaniu przestrzennym, rozwijając reguły socjotechniki urbanistycznej [Pióro 1980]. Przez lata, pomimo podnoszenia problemu niedostatecznej współpracy opisywanych dziedzin, niewiele na tym polu się zmieniło. Ustawa o planowaniu i zagospodarowaniu przestrzennym [Ustawa z 27 marca 2003] wyznaczająca ramy praktycznych działań kreujących ład przestrzenny nie obliguje do włączania socjologów czy ich dorobku. Z praktyki wiadomo, że braki te w wielu aspektach ujawniają się trudnościami natury społecznej czy nawet utrudniają procedurę planistyczną.

$\mathrm{Na}$ tym właśnie polu wyrosła pilna potrzeba wprowadzenia oraz dyskusji nad czynnym przeniesieniem narzędzi socjologicznych na grunt gospodarki przestrzennej. W ostatnich latach takiego zadania podjął się zespół pod kierownictwem A. Karwińskiej, proponując rozumienie socjotechniki urbanistycznej jako „wiedzy praktycznej, której celem jest rozpoznanie związków między rozmaitymi elementami materialnymi i niematerialnymi składającymi się na miasto oraz wskazywanie na możliwości działań zmierzających do osiągania zamierzonych celów w funkcjonowaniu miasta i jego rozwoju. Te możliwe działania mogą być podejmowane na różnych poziomach - od skali całego miasta, poprzez dzielnice, osiedla, do mikrośrodowisk społecznych (np. grup mieszkańców, poszczególnych instytucji itp.)" [Karwińska (red.) 2015, s. 47].

\section{Procedura dyrektyw socjotechnicznych}

Paradygmat socjotechniczny, będący metodologicznym rdzeniem socjotechniki, opisywany jest jako tok postępowania celowościowego. A. Podgórecki [1966] zaprezentował sekwencję składającą się z siedmiu działań. Schemat ten był punktem wyjścia do zastosowania dyrektyw socjotechniki urbanistycznej w gospodarce przestrzennej. Przeprowadzono odpowiednie modyfikacje, aby umożliwić zastosowanie go w kwestach związanych z planowaniem i funkcjonowaniem miast, a także 
w procesach monitorowania zmian zachodzących w miastach oraz ustaleniu kierunku dalszych przemian.

Chcąc stworzyć dyrektywy socjotechniczne, trzeba było wyjść od rozważenia hierarchicznego porządku priorytetów i ideologicznych wartości. W planowaniu przestrzennym były to przede wszystkim kwestie zaproponowane przez Państwową Radę Gospodarki Przestrzennej [Ministerstwo Infrastruktury i Rozwoju 2011]. Zostały tu podniesione m.in.: ochrona przed rozpraszaniem zabudowy, wprowadzanie równowagi między strefami funkcjonalnymi, konflikty w przestrzeni, usprawnienie systemu planowania, zwiększenie efektywności systemu instytucjonalnego, wdrażanie instrumentów ekonomicznych do systemu gospodarowania przestrzenią, zreformowanie nadzoru urbanistycznego i budowlanego czy zbudowanie systemu monitorowania zmian $\mathrm{w}$ przestrzeni. Jeśli chodzi o funkcjonowanie miasta $\mathrm{w}$ sferze fizycznej i przestrzennej, to jako priorytety i wartości ideologiczne zostały tu przyporządkowane takie kwestie, jak m.in. przeciwdziałanie rozlewaniu się miast, rewitalizacja, reurbanizacja wielkich osiedli mieszkaniowych, ochrona dziedzictwa kulturowego i przyrodniczego czy zrównoważony system transportu w miastach. Jeśli wziąć pod uwagę monitorowanie funkcjonowania miast, priorytetowe w tym zakresie są działania oceniające ład przestrzenny w miastach. Można tu wspomnieć m.in. o zmiennych: opisujących cechy funkcjonalne, społeczno-gospodarczych, środowiskowych, kulturowych, kompozycyjno-estetycznych [Górczyńska 2012] czy też o propozycjach Z. Ziobrowskiego [1992].

Kolejnym etapem dochodzenia do dyrektyw socjotechnicznych na potrzeby gospodarki przestrzennej zgodnie $\mathrm{z}$ tokiem postępowania celowościowego $\mathrm{w}$ socjotechnice było przeprowadzenie dokładnej diagnozy sytuacji stanowiącej problem [Karwińska (red.) 2015]. Analizując procesy planistyczne, opierała się ona na zapisach Ustawy o planowaniu i zagospodarowaniu przestrzennym [Ustawa z 27 marca 2003] przyjętych jako ramy wszelkich działań praktycznych w tym zakresie. Przestudiowany został podział na poszczególne szczeble planowania przestrzennego w Polsce, $\mathrm{z}$ analizą kompetencji, jakie za tym idą, oraz dokumenty planistyczne będące podstawą polityki planistycznej i prawa miejscowego. W zakresie funkcjonowania miast diagnoza była prowadzona wielowątkowo i obejmowała zagadnienia: niekontrolowanej urbanizacji, rozważania nad obecną formą miast, przestrzeniami otwartymi czy komunikacją. Jeśli chodzi o monitorowanie funkcjonowania miast, to diagnoza odnosiła się do rozważań nad dostępnymi metodami i narzędziami badawczymi oraz rodzajem danych (ilościowe, jakościowe). Ponadto monitorowane mogą być różne łady, np. społeczny, ekonomiczny, ekologiczny czy estetyczny.

Następnym etapem było dokonanie oceny sytuacji będącej przedmiotem diagnozy. Jeśli chodzi o procesy i dokumenty planistyczne, to podstawowa refleksja w tym względzie zamykała się w słowie - kryzys. Praktyka planistyczna oraz liczne analizy naukowe niestety tylko potwierdzają taki stan. Niejasności, uchybienia i liczne braki dotyczą przede wszystkim ustawodawstwa, które bezpośrednio oddziałuje na sferę przestrzenną polskich miast. W ocenie natomiast funkcjonowania miast na plan 
Agnieszka Brzosko-Sermak

pierwszy wysuwa się problem nieprzemyślanych i chaotycznych procesów urbanizacyjnych, w szczególności zagospodarowywania obszarów niezabudowanych oraz terenów przyrodniczych. Negatywnie oceniane są też m.in. komunikacja, rozczłonkowanie miast, degradacja centrów miast, grodzenie przestrzeni oraz coraz mniejsza liczba terenów otwartych. Natomiast ocena monitoringu zmian przestrzennych w miastach jest uzależniona od sposobu jego przeprowadzenia w poszczególnych jednostkach, gdyż nie ma ujednoliconego prawa w tym zakresie.

Kolejnym etapem tworzenia dyrektyw socjotechniki urbanistycznej było stworzenie hipotez teoretycznych wynikających z uprzednich diagnoz $i$ analiz. Następnie hipotezy te zostały zmienione w plan działania, dając już konkretne dyrektywy.

\section{Zastosowanie socjotechniki w gospodarce przestrzennej - przykłady}

Przykładem stworzenia planu działania w gospodarce przestrzennej opartego na dyrektywach socjotechniki urbanistycznej mogą być poniższe propozycje. Przede wszystkim w zakresie planowania przestrzennego poprawy wymaga sfera ustawodawcza. Dyrektywy w tym zakresie mogą brzmieć następująco: aby usprawnić działania planistyczne polskich miast, należy wprowadzić zmiany ustawodawcze, eliminujące wady prawne, niejednoznaczność interpretacji czy relacje między poszczególnymi dokumentami; aby miasta mogły rozwijać się harmonijnie, należy w dokumentach planistycznych wprowadzać spójne, lecz elastyczne zapisy o odległym horyzoncie czasowym, a same dokumenty tworzyć konsekwentnie, bez zmiany ich co kilka lat; aby miasta mogły lepiej funkcjonować, to planowanie przestrzenne powinno odnosić się do kompleksowych działań dotyczących całego terytorium, wszystkich sfer życia i funkcjonowania [Karwińska (red.) 2015, s. 61-62].

W zakresie funkcjonowania miasta dyrektywy socjotechniki urbanistycznej mogą brzmieć następująco: aby miasto sprawnie funkcjonowało, należy przeciwdziałać intensywnemu zagospodarowaniu większości gruntów niezabudowanych lub ekstensywnie zabudowanych bez robienia analiz i bilansów zapotrzebowania na tego typu zagospodarowanie; aby miasto funkcjonowało w bardziej ekonomiczny sposób, należy utrzymywać zwartą formę, bez zabudowywania terenów otwartych, cennych przyrodniczo, korytarzy ekologicznych i komunikacyjnych; aby miasto funkcjonowało w harmonijny sposób, trzeba dbać o łatwy dostęp mieszkańców do przestrzeni publicznych i usług, jednocześnie przeciwdziałając procesom segregacji przestrzennej i dezintegracji społecznej [Karwińska (red.) 2015, s. 66].

Biorąc pod uwage aspekty monitorowania funkcjonowania miast, dyrektywy socjotechniki urbanistycznej powinny odnosić się przede wszystkim do planu wdrożenia wskaźników, które byłyby uniwersalne i porównywalne między miastami, wskazywałyby kierunek przyszłych zmian w przestrzeni, byłyby elastyczne, uwzględniające zróżnicowanie i zmienność sytuacji w miastach w czasie i przestrzeni oraz weryfikowalne w miarę postępu nauki, dzięki czemu możliwa będzie ich aktualizacja [Karwińska (red.) 2015, s. 72]. 


\section{Zakończenie}

Przyszłość polskich miast, to, czy chaos urbanistyczny i „bylejakość” przestrzeni będą się pogłębiać, zależy od odpowiedniego ukierunkowania zmian wprowadzanych za pomocą planowania przestrzennego oraz kierowania ich funkcjonowaniem. Autorka zaprezentowała jeden z pomysłów na przeprowadzenie tego typu działań, łącząc różne dziedziny naukowe, a co ważniejsze, dogłębnie analizując sytuację i dążąc do jak najracjonalniejszego jej rozwiązania.

W artykule zaprezentowana została wcześniej rzadko wspominana oraz zmodyfikowana koncepcja socjotechniki urbanistycznej wraz z jej podstawowymi narzędziem, jakimi są dyrektywy socjotechniki urbanistycznej, które mogą być stosowane na różnych poziomach, od skali całego miasta po grupy społeczne.

Wnioski dla przyszłego rozwoju miast odnoszą się do najpilniejszych działań, jakie muszą być podjęte w polskich jednostkach osadniczych. Należą do nich m.in. zmiany legislacyjne, rozlewanie się miast, kształtowanie obszarów śródmiejskich, terenów otwartych i przestrzeni publicznych, komunikacja czy chaos wizualny.

\section{Literatura}

Domański R., 2016, Gospodarka przestrzenna. Podstawy teoretyczne, Wydawnictwo Naukowe PWN, Warszawa.

Frieskie K.W., 2000, Socjotechnika - wyznanie niewiary, [w:] Socjotechnika. Kontrowersje, rozwój, perspektywy, red. J. Kubin, J. Kwaśniewski, Instytut Profilaktyki Społecznej i Resocjalizacji UW, PTS - Sekcja Socjotechniki, Warszawa.

Górczyńska M., 2012, Wskaźniki zagospodarowania i ładu przestrzennego w miastach i na obszarach silnie zurbanizowanych, [w:] Propozycje wskaźników do oceny i monitorowania zagospodarowania przestrzennego $w$ gminach ze szczególnym uwzględnieniem zagadnienia ładu przestrzennego, Raport z prac wykonanych w I i II etapie, Instytut Geografii i Przestrzennego Zagospodarowania PAN, Warszawa.

Jałowiecki B., 1968, Zastosowania socjologii w planowaniu przestrzennym, [w:] Socjotechnika. Praktyczne zastosowania socjologii, red. A. Podgórecki, Książka i Wiedza, Warszawa.

Karwińska A., 2008, Gospodarka przestrzenna. Uwarunkowania społeczno-kulturowe, PWN, Warszawa.

Karwińska A. (red.), 2015, Poszukiwanie rozwiąań dla współczesnych miast. Przykładowe obszary interwencji socjotechnicznych, Uniwersytet Ekonomiczny w Krakowie, Fundacja Uniwersytetu Ekonomicznego w Krakowie, Kraków.

Kubin J., 2000, Wstęp, [w:] Socjotechnika. Kontrowersje, rozwój, perspektywy, red. J. Kubin, J. Kwaśniewski, Instytut Profilaktyki Społecznej i Resocjalizacji UW, PTS - Sekcja Socjotechniki, Warszawa.

Kwaśniewski J., 2000, Perspektywy socjotechniki a megasocjologia, [w:] Socjotechnika. Kontrowersje, rozwój, perspektywy, red. J. Kubin, J. Kwaśniewski, Instytut Profilaktyki Społecznej i Resocjalizacji UW, PTS - Sekcja Socjotechniki, Warszawa.

Majer A., 2010, Socjologia i przestrzeń miejska, Wydawnictwo Naukowe PWN, Warszawa.

Ministerstwo Infrastruktury i Rozwoju, Stanowisko Państwowej Rady Gospodarki Przestrzennej w sprawie systemu gospodarki przestrzennej i planowania przestrzennego przyjęte na posiedzeniu Rady dnia 30 maja 2011. 
Parysek J., 2006, Wprowadzenie do gospodarki przestrzennej, Wydawnictwo Naukowe Uniwersytetu im. Adama Mickiewicza w Poznaniu, Poznań.

Pióro Z., 1980, Socjologia i urbanistyka, [w:] Planowanie społecznego rozwoju miast i społeczności terytorialnych a badania socjologiczne, red. S. Nowakowski, W. Mirowski, Ossolineum, Wrocław. Podgórecki A., 1966, Zasady socjotechniki, Wiedza Powszechna, Warszawa.

Przecławski K., 1964, Socjologia a urbanistyka, [w:] Socjologiczne problemy miasta polskiego, red. S. Nowakowski, PWN, Warszawa.

Ustawa z dnia 27 marca 2003 r. o planowaniu i zagospodarowaniu przestrzennym, Dz.U. 2003, nr 80 poz. $717, \mathrm{z}$ późn. $\mathrm{zm}$.

Ziobrowski Z., 1992, Mierniki jakości przestrzeni miejskiej, Instytut Gospodarki Przestrzennej i Komunalnej, Warszawa. 